\title{
"Lock the Granary, Peggy": Rhetorical Appeals to Rural Women in the Woman's Standard, 1886-1911
}

\author{
STEPHANIE GROSSNICKLE-BATTERTON
}

So lock the granary Peggy, and make the hencoop stout, Put the hogs back in the orchard, and turn the cattle out, Hide the horses on the hillside, and should the assessor come We'll lock the door and make believe the folks are not at home.

The women then we'll rally, for this is woman's cause, We'll tell them that we've learned a way to aid in making laws. We'll do no work but only sing and shout from roof and steeple, We'll cook your meals and pay our tax, when you admit that we are people. ${ }^{1}$

IN OCTOBER 1886, the Woman's Standard, a monthly newspaper produced by the Iowa Woman Suffrage Association, ran a poem titled "We the People" on the front page of its second issue. Invoking a figure named "Peggy" as a stand-in for the reader, the poem began and ended with a call to "lock the granary" until women had the right to vote. Sandwiched between was a discussion of the emptiness of the phrase "We the people," complete with a historical lesson on various injustices from the American

The author would like to thank the State Historical Society of Iowa for its generous support of this project in the form of a research grant. Gratitude also goes to editor Marvin Bergman and the Annals of Iowa's anonymous reviewers for their astute comments to improve the article, and to Leslie Schwalm, who provided valuable guidance in the early stages of this project.

1. Rebecca Dare, “We the People," Woman's Standard 1:2 (Oct. 1886), 1 (hereafter abbreviated as WS). Many of the articles in the Woman's Standard have no author or title. If there is one, I provide it in the text or in the footnote. I accessed the Woman's Standard digitally through The Gerritsen Collection of Aletta H. Jacobs: gerritsen.chadwyck.com.

THE ANNALS OF IOWA 75 (Fall 2016). (C) State Historical Society of Iowa, 2016. 


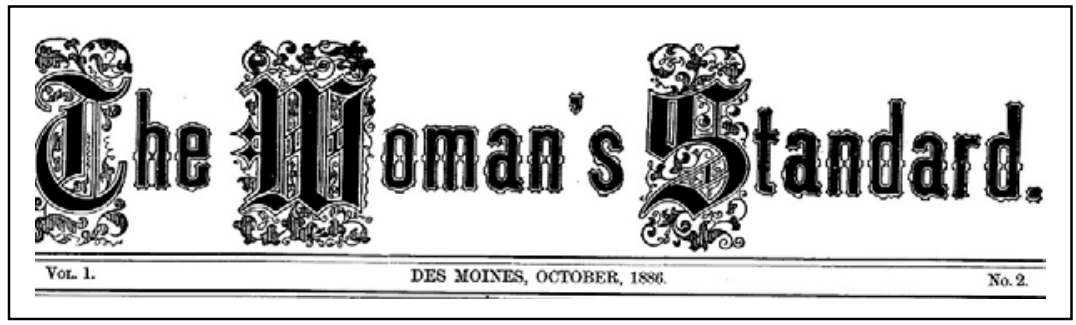

Revolution to present. The poem's democratic appeals and robust calls for woman suffrage were couched within a distinctly rural context, imagining a female reader who would "put the hogs back in the orchard, and turn the cattle out."

This convergence of rural identity with the suffrage cause would continue throughout the Woman's Standard's 25-year run. A close analysis of the paper reveals that suffrage workers in Iowa appealed in distinct and intentional ways to their rural audience in the pages of the paper. In doing so, the Standard also became a space - albeit limited - for some rural women to articulate concerns, air grievances, and find validation for their lives on farms.

The Woman's Standard served as the official organ of the Iowa Woman Suffrage Association (IWSA) from 1886 to 1911.2 Begun in 1886 by former IWSA president Martha Callanan and based in Des Moines, the newspaper initially proposed to run for one year, unless it received enough support to continue. According to an announcement in its first issue, the newspaper would join "the on-coming tide of the world's thought" in demanding "the equality of all classes of citizens." ${ }^{3}$ The paper lived long past the initial one-year commitment, publishing monthly issues nearly every year through 1911.4

2. The IWSA (later known as the Iowa Equal Suffrage Association) was formed in 1870 at a Mount Pleasant convention called by Quaker Joseph Dugdale. For more information on the IWSA, see Louise R. Noun, Strong-Minded Women: The Emergence of the Woman-Suffrage Movement in Iowa (Ames, 1969), 133-42.

3. WS 1:1 (Sept. 1886), 1. Throughout its run, the Standard's place of publication changed depending on the management, including Des Moines (1886-1897, 1910-1911), Sutherland (1897-1899), and Waterloo (1899-1910). Editors included Mary Jane Coggeshall, Evelyn M. Russell, Lizzie B. Read, Carrie Chapman Catt, Katherine M. Pierce, Roma W. Woods, and J . O. Stevenson.

4. The Standard suspended publication for 18 months between 1894 and 1896. In August 1894 editor Katherine Pierce cited "financial depression" as the cause of the suspension. Publication resumed in March 1896, with Pierce still at the helm, 
It is difficult to determine readership statistics for the Standard, especially across its entire time span. By 1901, however, the paper was telling advertisers that 2,000 copies were distributed to 400 towns. ${ }^{5}$ Most likely the readership consisted of the relatively small group of suffrage workers within Iowa and those they came into contact with who were receptive to the cause. Small suffrage papers like the Standard may not have had as many subscribers as general newspapers of the time, yet they remain a vital area of study because of their importance to the suffrage movement and women's lives at the turn of the century.

Scholars have identified several key functions of the suffrage press, including the ability to reach larger, more geographically diverse audiences than lectures and to connect local suffragists with national and state action. Publications also created community among suffrage supporters, reminding readers of shared burdens and successes. According to Martha Solomon, each paper "sought its niche by creating a distinctive blend of materials for various segments of the audience," even though the common theme of women's rights bound the readers together. ${ }^{6}$

The geographical context of the Standard illustrates this. Based first in Des Moines and later in Waterloo and Sutherland, and run largely by women and men who had moved to Iowa from the East, the IWSA's paper was clearly targeted to an audience that included many urban, middle-class women. However, it also needed to appeal to Iowa's large rural population. The content of the paper generally reveals this breakdown; most of the content is similar to other mainstream or national suffrage newspapers of the time, often including reports from suffrage conventions, updates on laws related to the cause in various parts of the country, and many opinion pieces on the history of

but the paper was reduced from eight pages to four pages per issue. See WS 8:12 (August 1894) and 9:1 (March 1896). Callanan would continue to publish the paper until 1899, when Sarah Ware Whitney took it over.

5. “A Few Words with Advertisers," WS 14:1 (March 1901), 2. The editor noted that about half of the subscription list was women. Hereafter, I refer to the Woman's Standard as the Standard, as most writers in the paper did, even though the official title remained The Woman's Standard throughout its run.

6. E. Claire Jerry, "The Role of Newspapers in the Nineteenth Century Woman's Movement," in A Voice of Their Own: The Woman Suffrage Press, 1840-1910, ed. Martha M. Solomon (Tuscaloosa, AL, 1991), 28; Martha Solomon, "The Role of the Suffrage Press in the Woman's Rights Movement," ibid., 14. 
women's rights and the varied reasons for expanding them. However, rural themes, including articles related to farming, make up a small, but significant portion of the paper's subject matter. ${ }^{7}$

The presence of rural themes in the Woman's Standard illuminates how the woman suffrage movement in Iowa appealed to and involved rural women, a topic that has not received much attention from scholars until recently. ${ }^{8}$ Sara Egge has done the most substantial and critical work on the relationship between the suffrage movement in Iowa and rural women. Noting the dearth of scholarly work on rural women and the suffrage movement and the assumptions on the part of some scholars that rural women were not interested in suffrage work, Egge shows that "in Iowa, farm women were neither ignorant nor uninterested" in the cause, and suffrage leaders adapted their efforts and tactics from 1870 to 1920 to involve farm women in their campaign. ${ }^{9}$ Analyzing the presence of rural women and the issues important to

7. Some issues of the Standard included six or seven articles in which rural themes can be identified, while other issues contained none. Most contained at least one or two. The total amount of content in each issue varied throughout the Standard's run. In early issues with eight pages, 30 to 40 pieces of content could appear in a single issue; after the paper was reduced to four pages in 1896, the content usually included 15 to 20 submissions or reprints.

8. Louise R. Noun's Strong-Minded Women includes biographies of the early leaders in the Iowa movement but does not take up rural suffrage work directly, especially since many of the figures moved from the East to Iowa, often settling in Des Moines or other urban Iowa locales. Glenda Riley's extensive scholarship on the women of the plains and prairies in the nineteenth century includes limited discussion of suffrage work, which provides valuable context for understanding the challenges suffragists faced. Exploring the ways the frontier necessitated the modification of women's roles in midwestern and western states, Riley points out that those modifications were "not deep-seated enough to underwrite such a major revision of policy as extension of suffrage to women." Thus, even though prairie states debated several suffrage bills, mostlike Iowa-did not enact suffrage until the passage of the Nineteenth Amendment. Glenda Riley, The Female Frontier: A Comparative View of Women on the Prairie and the Plains (Lawrence, KS, 1988), 172.

9. Sara Anne Egge, "The Grassroots Diffusion of the Woman Suffrage Movement in Iowa: The IESA, Rural Women, and the Right to Vote" (M.A. thesis, Iowa State University, 2009), 4, 6. For further context on rural suffrage efforts in Iowa and the Midwest, see Egge's other works: "'Strewn Knee Deep in Literature': A Material Analysis of Print Propaganda and Woman Suffrage," Agricultural History 88 (2014), 591-605; and "'When We Get to Voting: Rural Women, Community, Gender, and Woman Suffrage in the Midwest" (Ph.D. diss., Iowa State University, 2012). 
them in the Standard extends this scholarship by turning attention to a text largely neglected in previous studies, despite its 25year run. ${ }^{10}$

Throughout its run, the Standard incorporated rural themes in its rhetoric, showed evidence of suffrage work in rural areas, and to varying degrees became a counterpublic space for rural women where contributors explored issues relevant to Iowa farm women. The inclusion of rural issues such as property rights and gendered farm labor reveals the lived experiences of many farm women as well as the popular images of farm life circulating in the media at the time. The Standard's focus on suffrage work at places such as state and county fairs shows how the suffrage movement sought to include a variety of women. Yet analyzing the notions of rural identity included in the paper also reveals the many women who were excluded from the movement based on race or class.

THE SUFFRAGISTS who wrote in the Woman's Standard understood the need for consciousness-raising among Iowa's rural populations. According to the concept of consciousness-raising, members of an oppressed group, in order to effect change, must first become aware of their oppression and then become empowered to act as agents of change to combat that oppression. However, suffragists faced barriers in getting their message out and convincing women that they could become agents of change since, according to feminist rhetoric scholar Karlyn Kohrs Campbell, "a central element in woman's oppression was the denial of her right to speak." 11

The Standard addressed those two concerns directly in its first issue, laying out the paper's justification and goals:

To suppress the full utterance of the moral convictions of a class which so largely molds the character of the race is a crime against

10. Egge does not take up the Standard as an object of study, mentioning it only once in relation to a local suffrage society distributing copies of it to ministers in their town in 1906. Egge, "The Grassroots Diffusion," 33. Noun also says little about the newspaper, mainly because the bulk of her study focuses on the years before 1886. When she does use the Standard, it is as a source of information about one of the women she profiles.

11. Karlyn Kohrs Campbell, Man Cannot Speak for Her, vol. 1, A Critical Study of Early Feminist Rhetoric (Westport, CT, 1989), 9. 
humanity - against progress - against God. Believing this, and that the cause demands a wider hearing than has yet been given by even the many friendly papers of the State, the friends of Woman Suffrage in Iowa now speak to the public through the freer channel of their own paper. ${ }^{12}$

Thus, from the beginning the Standard sought to give women a political voice and spread the message to a wider audience so they could correct this "crime against humanity."

For Iowa suffragists, rural women made up a key part of that wider audience. The inaugural issue suggests that the Standard provided an important way to link the campaign to rural areas specifically. The suffrage cause needed "plain presentations of woman suffrage before country audiences," and the Standard was one of the "surest ways to convert a family" in the country to the "gospel of woman suffrage." 13 To raise their consciousness, or "convert" their audiences to the cause, the suffragists writing in the Standard tailored their rhetorical appeals to fit the rural context within which they operated, using rural metaphors and emphasizing themes relevant to life on the farm, including the intensity and peculiarities of labor and isolation on the farm and the issue of property and inheritance rights. In doing so, many of the writers invited readers to connect their lives on the farm with the larger cause of women's equality.

One technique writers deployed in the Standard was to use imagery rooted in farm life to describe suffrage work. Such language often included standard metaphors common in general communication, such as "planting seeds" and "reaping the harvest," but in many cases, as in the poem in the epigraph, writers went further to include specific imagery familiar to a rural audience. In a November 1890 piece titled "The Philosophy of Delay," for example, editor Lizzie Bunnel Read encouraged readers to be patient as they waited for their suffrage work to yield results. Using several paragraphs to detail the development and growth of an ear of corn, she explained, "Time must enter into the product. The tissues must ripen, the fibers must toughen." She went on to advise her readers that they, like farmers, must continue to work

12. WS 1:1 (Sept. 1886), 1.

13. Ibid, 4. 
while they wait on the harvest, "for in due time we shall reap, if we faint not." 14

A few months later, Read began a piece with an excerpt from a farm journal about how to bring up colts in a proper way. She then used descriptions of horses and cows to illustrate how women had not been able to thrive in the country. She contrasted the Jersey cow's ability to grow larger on the prairies of the Midwest with the way men "left women to subsist upon the weeds and brambles their well-fed tastes had rejected," all the while calling them "the pony sex." Her solution was for women to demand that men "pass the meat around, let the women into fresh pastures; give them a generous allowance of oats" so that they would no longer remain the "pony breed." 15 Here Read took the term "pony breed," a condescending term men were using to describe women, and put the onus for this condition back on the men of the time, extending the animal caretaking metaphor.

Read was not a farmer or a farmer's wife, nor do we know how her message was received or interpreted by rural women who may have read the paper. ${ }^{16}$ Nevertheless, the fact that she used such detailed knowledge of corn production and breed-specific terminology to resonate with her audience suggests that the imagined community of the Standard did include readers with at least a background in farming. ${ }^{17}$ Language rooted in a farming context also shows how suffrage workers like Read recognized and incorporated Iowa's agricultural identity into their campaigns.

At times, writers in the Standard would use this agricultural identity to make larger claims about national identity. In a February 1887 piece, "When the Hens Begin to Lay," the unnamed

14. Lizzie B. Read, “The Philosophy of Delay,” WS 5:3 (Nov. 1890), 3.

15. Lizzie B. Read, “The Pony Breed,” WS 5:6 (Feb. 1891), 5.

16. According to census records, Read's husband was a physician and operated a drug store. They lived in the incorporated town of Algona. 1880 U.S. Census, Kossuth County, Iowa, population schedule, Algona, p. 283 (stamped), dwelling 60, family 60, Samuel A. Read and Lizzie B. Read, digital image, AncestryLibrary.com.

17. For the concept of "imagined communities," see Benedict Anderson, Imagined Communities: Reflections on the Origin and Spread of Nationalism (London, 2006). Anderson focuses on the relationship between print capitalism and the development of the nation-state but pays special attention to the role of newspapers in creating imagined communities. 
author began by explaining how women who could not afford to pay 50 cents for a yearly subscription to the Standard could sell eggs to offset the cost. Moving from the personal to the national, the article went on to claim, "From the letters which come from many rural homes accompanying the modest fifty cents, we are led to believe that the founders of this great government, where the opinions of women are not counted, have made a mistake in choosing the typical American bird." The national symbol should not be the eagle, nor even "the pompous hero of the barnyard that vociferously calls his speckled harem about him just in time to see him gobble the precious worm." Instead, the Standard found the "practical hen" more fitting, as she "is helping the American woman to solve the problem of her independence." 18 Here the hen not only served a practical function of providing financial means to buy the paper and become connected to the wider suffrage movement. The author also suggested replacing the eagle as the national symbol and found a proper replacement not in the rooster but in the hen. It is notable that hens are not only female but also part of the female sphere on the farm and could even provide a means of independent income for farm women. ${ }^{19}$ Hence, this rewriting could serve as an empowering image for rural women to connect their daily lives to the suffrage cause and the very essence of the nation.

IN ADDITION to using rural themes for metaphorical purposes, the paper used subjects of concern to rural women to gain support for the suffrage effort. One of those was the portrayal of the hardships of life on the farm, most notably loneliness and labor, which many agricultural reformers and mainstream writers of the time described as "drudgery." One particularly evocative story titled "Causes of Insanity" claimed that an Iowa State Board of Health doctor found that insanity was increasing the most in the agricultural classes. Adding its editorial opinion, the Standard blamed this on the isolation of farm life. "The farmer and his wife

18. “When the Hens Begin to Lay,” WS 1:6 (Feb. 1887), 5.

19. For a thorough discussion of female- and male-centered activities on the farm, see Mary Neth, Preserving the Family Farm: Women, Community and the Foundations of Agribusiness in the Midwest, 1900-1940 (Baltimore, 1995). 
are often denied the pleasure of the society of others and are left alone for a great part of the time to brood over their own thoughts ... with no cheering or sympathetic hearing from the outside." The loneliness of farm life was not always portrayed as a cause of insanity, but it was certainly a cause of concern throughout the newspaper. ${ }^{20}$

One proposed solution for this isolation was for women to participate in their local temperance or suffrage association. A July 1888 article, "How Farmer's Wives in Kansas Go to Suffrage Meetings," included a summary of an article from the Woman's Tribune detailing three different farmers who had made sure their wives could attend the local suffrage meeting in Kansas. Two had kept the children nearby as they did farm work to facilitate their wives' absence; the other had allowed the use of field horses for transportation because he realized that "his wife needed an outing every once in a while." 21 Whether this actually happened or not, the Standard used the story to show how suffrage meetings extended beyond work and into the social realm. An article like this could serve to convince women of the importance of attending meetings, encourage workers that small successes were happening, and portray farm husbands as potential allies - rather than enemies - in the suffrage struggle.

Articles, stories, poems, brief news reports, and jokes covered the subject of overwork, often described as drudgery. Writers described the state of farm life for women in terms as mild as "not what it is cracked up to be" or as dire as a "life destroying labor" and "as near slavery as we care to imagine anything." 22 The stories

20. "The Cause of Insanity," WS 2:11 (July 1888), 3. The issue of isolation on the farm was especially prescient for women, whose duties at home might keep them from traveling with their husbands when the latter would go to town or meet with other farmers. Writers took up this topic frequently. For example, Susan Glaspell's 1916 play Trifles and 1927 short story "A Jury of her Peers" were both based on the 1900 murder of Iowa farmer John Hossack. Hossack's wife was accused of the murder, and the play and story lay the blame, in part, on her isolation as a rural farm wife and her husband's refusal to recognize that isolation as a problem.

21. "How Farmer's Wives in Kansas Go to Suffrage Meetings, WS 2:11 (July 1888), 8.

22. WS 1:2 (Oct. 1886), 8; C. F. Clarkson, “Farm Economies," WS 2:11 (July 1888),

5; Editor's note, WS 8:9 (May 1894), 7. 
usually portrayed men as unable to understand their wives' plights and unwilling to hire help for them. (The Kansas story is a notable exception.) Many writers pointed out that men were quick to acquire labor-saving devices for their work in the fields but not for the work typically done by their wives. One article lamented that despite the importance of a farm wife's work, "the husband doesn't realize that she is working harder than any two men he has on the place, or if he does, that the work is killing her." 23

Mary Donley, a farm woman from Knoxville, emphasized the undervalued labor of most farm women in a piece wryly titled "God Made Women for Men to Take Care Of." Donley contended that although women do much labor on the farm inside and outside the house, many farmers neglect their wives' needs, instead spending the family's money on frivolities for themselves, such as tobacco. Out of the 52 farmers she counted around her, "but three of these" hired help for their wives in the house, even though farm wives typically engaged in a long litany of jobs on the farm, such as raising "hundreds of chickens every year." Donley concluded, "Surely if God did intend we live by the sweat of man's brow, we have greatly undervalued our privileges." 24

Stories such as Mary Donley's reflect the broader concern arising at the time over the state of farm women in the country. Labor on the farm began changing in the late nineteenth and early twentieth century for both men and women as reformers sought to elevate farming to middle-class status. In that model, farm women experienced increasing pressure from male agricultural reformers and professionals to become "professional homemakers." Historian Mary Neth writes, "The physical work of farm women not only clashed with middle-class status, but also made them 'unwomanly.' Such labor signified the inferiority of rural life. Professionals and the farm press portrayed farm women who worked in the field, and sometimes those who worked with live-

23. "Women on the Farm," WS 14:12 (Feb. 1902), 4.

24. Mary E. Donley, "God Made Women for Men to Take Care Of," WS 1:4 (Dec. 1886), 5. The 1880 census lists Mary E. Donley as the wife of Levi Donley of Knoxville, Marion County, with Levi's occupation cited as farmer and Mary's as "keeping house." 1880 U.S. Census, Marion County, Iowa, Knoxville Township, p. 54, dwelling 506, family 518, Levi O. Donley, digital image, AncestryLibrary.com. 
stock, as drudges. The middle-class farmer's wife, like her urban counterpart, worked only in the home, providing for her family." 25

In the case of the Standard, stories concerning farm women's work served multiple functions while addressing a diverse audience. For urban, middle-class readers, they could function much like other examples of women's oppression from around the world; their "shock value" could awaken outrage and renewed interest in the cause. Perhaps they also resonated with city and town readers who had grown up on farms. At the same time, for those readers who were still engaged in farming, stories like these could offer common commiseration and burden sharing. In his study of the Farmer's Wife, a Kansas newspaper that blended suffragist and populist goals, Thomas R. Burkholder argues, "The women on the prairie had envisioned themselves as alone, isolated both geographically and intellectually, and without power." 26 Through stories of hardship in newspapers like the Farmer's Wife and in articles like Mary Donley's in the Standard, suffragists drew attention to farm women's shared hardships and framed them as justifications for expanding their rights.

IN THE STANDARD, the tactic of describing farm women's labor as "drudgery" was often linked to claims that such labor violated the "proper spheres" prescribed for middle-class women of the time. On the one hand, writers sometimes portrayed this perceived violation as negative and used it to point out the hypocrisy of men who wanted to keep women from voting based on "proper place" arguments. On the other hand, writers could also present women's farm labor as a liberating and powerful celebration of women's ability to transcend rigid gender roles.

The Standard included many descriptions of women stepping out of the household to help on the farm. The inaugural issue of the paper included a story from a Pennsylvania newspaper reporting that three women assisted in harvesting and "completed almost as much work as any of the men." The Standard added, "But we did not hear that the good men of Shanesville held up their

25. Neth, Preserving the Family Farm, 215, 227-28.

26. Thomas R. Burkholder, “The Farmer's Wife, 1891-1894: Raising a Prairie Consciousness," in A Voice of Their Own, 163. 
hands in holy horror that these women were getting out of their 'sphere' or do we notice that the press of the country was greatly exercised about it." In a reprint from the Boston Herald, a farmer from Missouri bragged that his wife had "done more work than any other woman now living on earth." The Herald wondered what the farmer did "while his wife was doing all the work on the farm." 27 These examples reveal the varied attitudes toward women's farm work present in the newspaper. The first highlights the hypocrisy in the press's general condemnation of women's rights as a violation of separate spheres while that same press condoned a violation of separate spheres by a woman who helped her husband in his labors. The second operated more as an attack on the masculinity of men who would have women do farm work for them but presumably not allow them to vote or act in other ways perceived as "male."

R. D. Blaisdell Thorp, a farm woman and frequent contributor to the Standard, combined these two attitudes in an 1889 piece listing the multitude of tasks farm women engaged in daily. The Manchester resident wrote, "Since she [woman] has milked cows, and fed hogs, and helped doctor sick horses and herded cattle... without being 'unsexed' she has no fear of bringing that horror upon herself by voting even against her husband's firmly rooted opinions." 28 Thorp's reminder that women have been allowed to step out of their proper sphere when convenient for men supports Mary Neth's contention that "by emphasizing the cooperative and joint nature of the farm enterprises, [women] could define their work in ways that undercut the traditional and legal definitions of patriarchal power." ${ }^{29}$ In a similar way, stories in the Standard that highlighted how much work women did on the farm served as challenges to patriarchal rhetoric of the time and as support for the suffrage cause.

For Thorp and several other contributors to the Standard, women's labor in the fields was not mere "drudgery" but evi-

27. WS 1:1 (Sept. 1886), 5; WS 6:9 (May 1892), 7.

28. R. D. Blaisdell Thorp, “Are Women in Earnest?” WS 4:4 (Dec. 1889), 2; 1885 Iowa State Census, Delaware County, population schedule, p. 165 (stamped), dwelling 81, family 81, Justice B. \& Rosa D. Thorp, digital image, AncestryLibrary.com.

29. Neth, Preserving the Family Farm, 18. 
dence that women were just as capable as men. Reports of women successfully growing fruit in California or managing farms on their own in the Midwest dotted the Standard throughout the years. Such women often engaged in agriculture because of a husband's or father's death or incapacity, but not always. In one case, "Miss Jennie Gray," who worked a 160-acre farm, claimed that she "could work another one if the fellows who want to marry her and settle down would quit bothering her." In another, an Iowa woman who bought a farm in Nebraska found that "the earth yields her increase to faithful tillage regardless of sex." 30 Both of these examples showed women successfully engaged in agriculture without any connection to male family members. Such instances were aberrations, however. Most often, the examples of women's work on the farm pointed to the mutuality and partnership, rather than independence, that farm life entailed, leading contributors to the Standard to call for farmers to consider their wives equal partners in the management and ownership of the farm. ${ }^{31}$

MANY WRITERS in the Standard took up the topic of property rights, a theme that resonated with a wide variety of women but was especially pertinent for farm women. By 1886, Iowa had firmly established legislation ensuring single and married women's right to property held in their own names, as well as to any wages they earned. However, for women on farms, property rights were more complicated. Husbands often continued to hold sole ownership of the farm, despite their wives' significant investments in the labor and financial operation of them. ${ }^{32}$ Writers in the Standard began arguing that farms should be held jointly instead.

30. “Notes," WS 1:7 (March 1887), 1; “An Iowa Woman,” WS 2:10 (June 1888), 8.

31. In Preserving the Family Farm, Mary Neth explores how many farm women resisted urban, middle-class notions of women's work, taking pride in their physical labor and presenting it as evidence that they were "partners in a joint venture" (237).

32. Ruth A. Gallaher, Legal and Political Status of Women in Iowa (Iowa City, 1918), 91. The Iowa Code of 1851 allowed married women to retain the rights to property they held in their own name; the revised Code of 1873 ensured their rights to wages earned on their own. Gallaher points out that "property accumulated by them jointly was usually in the husband's name" (91). 
Significantly, the topic appeared in the very first issue of the newspaper. In "Equal Rights in Property," Lizzie Read, operating on the notion that "every farm in Iowa is a bank" and "ten thousand women in Iowa" were depositing their labor into such banks each day, insisted that women and men become joint owners of their farms to ensure that both had access to the benefits. ${ }^{33}$ Readers of the Standard who resided on farms agreed. In a letter to the paper in the following issue, R. D. Blaisdell Thorp expressed appreciation for Read's article, using striking language to invoke sympathy for the sacrifice women put into farms.

That "bank," the farm, has swallowed up all the earnings of many a woman's life, all the courage and all the hopes of her youth and all the pleasures of dress and books and travel that she so much desires in mature years. Too often they must all be given up for the improvement of the farm and the wife drudges along, year after year, her better nature starving for want of food. Her life goes to improve the farm, "which is as much yours as mine," her husband has often said, but she finds out the fallacy of that assertion when the home is made unendurable for her as it too often is.

Thorp, the wife of a farmer, presented male ownership of the farm as an all-too-common problem for rural women. She suggested that the Iowa suffrage paper could be an important vehicle for raising awareness about it; in the same article, she wrote, "I wish the STANDARD could go to every home in Iowa." 34

Nearly 20 years after this exchange, the reprinting of a speech from a farmer's institute held in Iowa showed that the issue was still relevant for many readers. In the April 1905 article "Partners on the Farm," Margaret Nicholson, the wife of a farmer from Ossian, Iowa, suggested that joint ownership of the farm should extend even beyond the mortgage documents. Echoing much of the language other writers used in the Standard, she included a list of a wife's many duties on the farm, but used it to show that women deserved a truly equal place in farm management. According to Nicholson, although a typical farm wife was expected to help in the fields, she "assume[d] one-half of the debt and none of the

33. Lizzie B. Read, "Equal Rights in Property," WS 1:1 (Sept. 1886), 6. Read would go on to serve as editor of the Standard from September 1890 to December 1892.

34. R. D. B. Thorp, “Equality in Marriage,” WS 1:2 (Oct. 1886), 3. 
credit." Nicholson insisted that a man's wife should instead be her husband's "helpmate and they two, captain and first mate, should be the ones to decide about the work and its profits." Nicholson maintained the established hierarchy of roles ("captain" and "first mate") but challenged the notion that men should solely control the profits. This is a notable resistance to the custom of the time; Mary Neth observes that "although, according to a 1920 survey, one-third of farm women in the central states kept the farm accounts, men controlled the financial and land resources and had both legal and customary control of management decisions on the farms." 35

Nicholson insisted not just on joint ownership of the farm's assets, but also on a revamping of how outsiders view the labor of women and men on farms and what should count as women's domain. Using the example of an assessor visiting the farm, she suggested that women should be asked questions about the farm - "how many bushels of corn" or "how many acres of ground do you have?" - instead of questions solely about how many children they have. She even went on to suggest that farms are unique in this partnership regard since "there can not be the same secrecy used as to investments that other trades will allow" when the family members are so dependent on one another in an isolated setting. ${ }^{36}$

As a speech given at a farmers' convention, Nicholson's essay was obviously suited to a rural audience; its presence in the Standard implies that Nicholson thought it appropriate enough to submit and the editor found it relevant enough to run. When it ran in April 1905, rural issues were clearly still a concern for the paper, and women were beginning to feel more willing to assert their opinions and rights in a public mixed-gender setting like a farmer's institute. ${ }^{37}$

35. Margaret Nicholson, "Partners on the Farm," WS 18:2 (April 1905), 1; Neth, Preserving the Family Farm, 20. Census records list Nicholson's husband's occupation as "farmer." 1900 U.S. Census, Winneshiek County, population schedule, Military Township, Sheet no. 8, dwelling 177, family 183, H. Pratt \& Margaret Nicholson, digital image, AncestryLibrary.com.

36. Nicholson, "Partners on the Farm," 1.

37. Women had been active in farmers' movements and organizations since the 1870s, but their roles within those organizations varied, generally evolving to become more active in the later years. The type of speech Nicholson gave to this 
A CLOSE READING of the Standard also shows that rural women had more than a rhetorical presence in the movement. Rural suffrage work was happening in the state, although the results seem mixed. In the paper's early years, the evidence of rural work included scattered reports from small towns and sparsely populated counties of suffragists attempting to make inroads or partnering with other local women's interest groups.

In 1892 the Standard ran several reports about IWSA chapters working with WCTU groups to hold "woman's days" at county fairs. According to suffrage worker Emily Phillips, these met with mixed reactions. At one, workers received "gracious attention" that seemed to indicate that "the way is now open for a strong organization." At another, officials "made not the least effort to have order and quiet prevail" during speeches." 38 By 1901, Phillips was still expressing a mix of despair and hope for her work in rural areas. In a letter dated February 24, 1901, she shared that reading the Standard had greatly helped "the few faithful ones who still hold the banner of equal suffrage aloft in this fossilized town." Yet she ended by stating, "We hope for some work over the county and many converts among the rural population. I think they are the voters whom we want to reach and they are usually the ones who give a careful hearing too, to our speakers." ${ }^{39}$ In many ways this reflected the sentiment suffragists expressed throughout the paper, regardless of geographic location. Workers in the movement endured long periods of work without strong results yet still expressed hope that the cause would eventually be won.

The increase in rural suffrage work in the years around the turn of the century was in part a response to calls from suffrage leaders to focus on rural areas. In an interview in the September

farmer's institute is much more assertive and bold than many of the earlier speeches from women within those movements. For a thorough discussion of the range and limits to women's self-expression in farmers' organizations and movements, see Donald B. Marti, Women of the Grange: Mutuality and Sisterhood in Rural America, 1866-1920 (New York, 1991).

38. "Van Buren County Fair,” WS 7:1 (Sept. 1892), 1; “Wapello County Fair,” WS 7:1 (Sept. 1892), 4. As was characteristic of many stories in the paper, Phillips continued to express hope even when met with little enthusiasm at the Wapello County Fair, telling readers that "some day our fair men may be glad to make conditions what they should be for such an occasion."

39. Emily Phillips, [untitled], WS 14:1 (March 1901), 2. 
1897 issue, Anna Shaw advised suffragists that "women's enfranchisement must come from the rural districts"; country women could become "the most zealous workers," she noted, because they are "the most tenacious of thought, not having so many things to dissipate it as the women of the cities." 40 Here, Shaw tried to turn the supposed isolation of farm life into an asset for the women's movement. In her view, women had less to distract them in the country. Those who wrote of the overburdening workload in the country may not have agreed with Shaw's assertion, but her words show that the movement's leaders saw the need for increased activism in rural communities.

With a renewed commitment to increase efforts in rural areas, suffrage proponents turned to the Standard as a vehicle to assist their endeavors. In October 1900 the Iowa Equal Suffrage Association's executive committee discussed the need to find "some woman in each quarter" of every county to "take up the Standard and make it her special work." Country post offices were suggested as the ideal place to talk with rural residents and "urge the Standard." 41

As Iowa suffrage workers called for increased work in rural areas and increased distribution of the Standard to assist in the effort, they also seized on the state's agricultural identity to increase their profile in the national suffrage movement. At the IWSA state convention in 1900, leaders announced that a national suffrage bazaar was to be held in New York in December where each state would send representative products. Eleanor Stockman of Cerro Gordo County suggested that Iowa women send a carload of pigs, and she volunteered to provide the first one. Carrie Chapman Catt, president of the National Woman Suffrage Association (NWSA), took to the Standard to encourage women to contribute to the effort by securing a pig to sell and donating the proceeds to the NWSA. Many women sent money in without having secured a pig and just asked that it be marked "pig money." Still, they collected enough pigs to fill a train car to be sold in Chicago. The proceeds were sent to the NWSA, and the canvas that covered the car was displayed at the bazaar to

40. “Charles City Convention,” WS 10:7 (Sept. 1897), 3-4.

41. IESA Ex. Com. Meeting, 10/19/1900, p. 3, folder 2, box 8, Iowa Women's Suffrage Collection, State Historical Society of Iowa, Des Moines. 
represent Iowa's contribution. The national superintendent of press work for the NWSA assured Iowans that "your state has had plenty of free advertising through the car load of hogs.... I think every paper in the United States made mention of it." 42 The "pig money" incident suggests that rural identity could be tied to suffrage efforts to gain support within the state and to help define Iowa's reputation in the national movement's imagination.

Thus, in many ways, the content of the Standard confirms Sara Egge's thesis that suffrage work was more limited in rural areas in the nineteenth century but increased substantially after the turn of the century. ${ }^{43}$ However, it also reveals that Iowa suffrage workers had been melding their efforts with rural identity on a grassroots level at least since the beginning of the paper's run in 1886. One key aspect of this was the suffrage movement's presence at the Iowa State Fair.

From 1886 through 1896, every issue of the Standard included a report on the state fair. In addition to describing the livestock, horticulture, and farm machinery exhibits, the reports detailed work done by the IWSA at each fair. In fact, the October 1886 report claimed that "the only permanent cottages built on the grounds by Iowa enterprise were by the Woman Suffrage and WCTU associations." Similar to accounts in future years, the reports noted that "a large amount of suffrage literature was distributed" and "over 1,400 names secured to the suffrage petition." The Standard also "found a welcome in many Iowa homes through this instrumentality." 44 The regular presence of state fair reports suggests that the IWSA not only had a presence at state

42. "Bazaar," WS 13:11 (Jan. 1901), 1. A digital search of four major newspapers of the time (Chicago Tribune, New York Times, Los Angeles Times, and Washington Post) found one mention of the "pig money" incident. "Suffrage Association's Pig," New York Times, 11/2/1900, 3.

43. Egge, "Grassroots Division," 6-7.

44. "State Fair," WS 1:2 (Oct. 1886), 5. In the 1880s and 1890s, suffragists had a visible presence at the fair. "Woman's Day" became a feature of fair week when suffragist Carrie Chapman Catt delivered an address in 1891. After the turn of the century, however, fair organizers discouraged political organizations like the IWSA from having a presence at the fair, eventually barring the organization from the Women's and Children's Building when it was constructed in 1913. See Chris Rasmussen, Carnival in the Countryside: The History of the Iowa State Fair (Iowa City, 2015), 76-78. 
fairs in the late nineteenth century but also appeared to view them as a vital way to reach out to a diverse group of people. 45

Overall, the Standard reflects a trend in rural women's work within the woman suffrage movement in Iowa after the turn of the century. In the paper's later years, there are reports from more chapters around the state and articles about activities such as parades and rallies, regardless of geographical setting. However, that increase likely would not have been possible without the earlier rural work that the Standard had highlighted. Participation in the state fair in the 1880s and leaders' advice to focus on rural areas in the 1890s are two examples of the ways the movement sought out rural women in the closing decades of the nineteenth century.

BEYOND the practical contributions the Standard made to the woman suffrage movement in Iowa, it also served a more abstract, but very real, community-building purpose. It created a sort of "counterpublic" space, a place where those who are otherwise not able to participate fully in public discussions are able to do so and where issues that are considered already settled or uncontestable in the wider discourse become open for contestation and discussion. ${ }^{46}$ Suffragist papers like the Standard exemplify the potentials and limits of this type of counterpublic. According to social theorist Nancy Fraser, "On the one hand [counterpublics] function as spaces of withdrawal and regroupment; on the other hand, they also function as bases and training grounds for agitation activities

45. Reports do not indicate where people who visited the suffrage building were from, so it is difficult to determine if the people who signed petitions and subscribed to the Standard at the fair were from rural or urban areas. However, the Standard's presence at an event strongly associated with agriculture and its reporting on the agricultural aspects of the fair is relevant here. For the Iowa State Fair's relationship with agriculture, see Rasmussen, Carnival in the Countryside.

46. Nancy Fraser introduces the concept of the subaltern counterpublic in "Rethinking the Public Sphere: A Contribution to the Critique of Actually Existing Democracy," Social Text No. 25/26 (1990), 67. Working with Jurgen Habermas's definition of the bourgeois public sphere as a site for citizens to deliberate ideas separate from - or in opposition to - the state, Fraser insists that many subaltern groups are left out of that public sphere and so must create alternative spaces where they "invent and circulate counterdiscourses, which in turn permit them to formulate oppositional interpretations of their identities, interests, and needs" (67). For more on the subject of counterpublics, see also Michael Warner, Publics and Counterpublics (New York, 2005). 
directed toward wider publics." 47 In this way, the Standard can be read as a counterpublic space for Iowa suffragists. It offered them a chance to find commonalities, experience a sense of solidarity, and participate in the consciousness-raising that is essential to any movement. The newspaper also served a larger purpose, beyond suffrage work; it developed a community where primarily women could rhetorically "gather" and discuss issues important to them.

The Standard's slogan points to this wider focus. Printed under each issue's masthead were the words, "The Woman's Standard will treat of the Home, Health, Purity, Culture, Temperance, Education, and of the legal and political interests of Woman, and of her right to the Franchise." 48 But what exactly did those concepts include? Did "the Home" include interests related to the farm? Did "Culture" include rural as well as urban identities?

Although the newspaper had always given some nod to issues affecting rural women, such as property rights and women's work on the farm, it was only later in its run that it began to branch out and include more articles related to rural concerns not overtly tied to women's rights. Notably, the Standard had always run reprints from agricultural newspapers that raised awareness of the farm woman's plight, but in later years the publication began to include information about broader farm issues. News about grassroots farm associations, irrigation techniques, and crop yields points to the Standard's larger rural context. ${ }^{49}$ Perhaps appealing to male farmers as important suffrage supporters, or perhaps based on the belief that farm women who read the paper would also be interested in farm-related news, including articles like these allowed the paper to address larger rural concerns in addition to suffrage-specific news.

Rural women could also turn to the Standard for validation of rural culture, although that certainly was not a focus of the newspaper. Images of overworked women or farmers driven insane dotted the paper, but those existed mainly as a way to emphasize the need for women to participate in the suffrage movement. At other times, writers upheld and valorized a rural way of life. One

47. Fraser, "Rethinking the Public Sphere," 68.

48. WS 1:1 (Sept. 1886), 1.

49. "The Male Fight for Equal Commercial Opportunity," WS 18:2 (April 1905), 1; “The Irrigation Outlook," WS 22:7 (Sept. 1909), 3. 
such example was a reprint titled "Farm Life" in the September 1891 issue. Extolling the virtues of boys raised on farms, the writer expressed the "notable fact that in the colleges of our country the best students are the boys from the farm. In the workshops, in the halls of legislation, at the bar, in the forum, the pulpit, ninetynine hundredths of the men who stand upon the summit were once boys on the farm." Attributing this success to "a constitution that endures labor," the writer went on to contrast the background of farm boys versus town boys: "They [farm boys] were barefooted, had tanned cheeks, wore patched clothes, and worked for bread." Meanwhile, boys in town were "fooling, brushing their hair and polishing their boots, while the rough country boy is plunging barefooted along the road to fame." 50 In this image, the author upheld farm life and an inversion took place - the hardships and poverty of farm life were signs that one was on the road to success, and the middle-class concerns for appearance and good grooming became signs that one was lacking the traits necessary for success. Since there was no girl in the piece (although the first line of the article mentioned boys and girls as the "grandest product of the farm"), readers could assume that the editors of the Standard thought a sufficient number of their readers would be interested in the general theme to run it.

Sentimental pieces like this exemplify the Jeffersonian ideal of the yeoman farmer, popular in mainstream culture. However, they could also serve to validate the experiences of readers who lived on farms or came from farm backgrounds. As Linda Steiner argues, newspapers marketed to rural audiences combatted middle-class notions of success by presenting farm women as "capable, intelligent, pragmatic, hard-nosed, and politically astute." 51 Pieces like "Farm Life" implied that farm women were capable of raising children who were all those things as well. By including pieces that celebrated rural life as equal to, or in some cases superior to, city life, the Standard spoke to rural people in its counterpublic sphere, even if not to the same extent as publications like the Farmer's Wife did.

50. “Farm Life," WS 6:1 (Sept. 1891), 3.

51. Linda Steiner, "Evolving Rhetorical Strategies/Evolving Identities," in A Voice of Their Own, 194. 
THE WOMAN'S STANDARD did not, however, give all voices and viewpoints equal weight; indeed, it left some out almost completely. A key limitation of counterpublics, Fraser contends, is that "even those with democratic and egalitarian intentions are not always above practicing their own modes of informal exclusion and marginalization." 52 The writings of Elvie N. Logsdon for the Standard illustrate the exclusion and marginalization present in this counterpublic sphere. Logsdon was the wife of a farmer, held various positions in the Decorah Equal Suffrage Association, including president, and wrote for the Standard on multiple occasions. ${ }^{53}$ In a 1906 article titled "Does the Indifference of Women Hinder Our Cause?" Logsdon answered the question in her title by pointing to the "stupidity, ignorance, and prejudice" of men as the main hindrance to the suffrage cause. In her explanation, Logsdon appealed to anti-immigrant rhetoric, claiming that men's "stupidity" stemmed from their insistence on protecting women from politics, never considering that their "immigration laws permit an influx of the ignorant, oppressed, and vicious of other lands to be our fellow citizens" and "gives us minors, idiots, insane, convicts, and incapables as our political equals." 54 If Logsdon was aware of the irony in decrying prejudice against (native-born white) women by using prejudice against immigrants to do so, she did not make it apparent in her piece.

As articles like Logsdon's indicate, the rural women included in the newspaper's imagined community were predominantly imagined as Anglo-Saxon. ${ }^{55}$ Following many of the other mainstream suffrage papers of the day, the Standard often subverted racial equality to the cause of woman suffrage. ${ }^{56}$ Although it ran

52. Fraser, "Rethinking the Public Sphere," 67.

53. 1900 U.S. Census, Winneshiek County, Iowa, population schedule Decorah Township, sheet 11, dwelling 218, family 227, John H. Logsdon \& Elvie N. Logsdon, digital image, AncestryLibrary.com.

54. E. N. Logsdon, “Does the Indifference of Women Hinder Our Cause?" WS 18:11 (Jan. 1906), 1.

55. A poem in the May 1893 issue, "Hans Dunderkopf's Views of Equality," juxtaposed a speaker's heavy German dialect and poor grammar with his refusal to allow his wife to vote, suggesting that anti-German sentiment was prevalent enough to be an effective way to appeal to audiences at the time. WS 7:9 (May 1893), 2.

56 . For more on the relationship between racism, nativism, and the mainstream woman suffrage movement, see Suzanne M. Marilley, Woman Suffrage and the 
some brief news bits about racial progress, for the most part the paper excluded racial issues or writers used them rhetorically to delegitimize minority rights in order to legitimize women's. ${ }^{57}$ The rural image that the Standard deployed excluded, and thus made invisible, the rural work of immigrant, African American, and Native American women at the time.

The presence of rural imagery and rural women in the Standard shows that, to some extent, the paper did become a counterpublic sphere in which writers could discuss the nature of womanhood, proper spheres, farm labor, and rural life. By including writings from farm women like Mary Donley, R. D. Blaisdell Thorp, Margaret Nicholson, and Elvie N. Logsdon, the paper gave space for certain rural women's voices. Yet the paper created boundaries around that space, often excluding racial and ethnic minorities' experiences or using them rhetorically to bolster the cause. 58

THE WOMAN'S STANDARD ended publication before it was ever able to report that suffragists had finally won the vote for women. The Iowa state legislature approved the Nineteenth Amendment on July 2, 1919; the Standard published its last issue in November $1911 .{ }^{59}$ Consistent with the attitude embodied throughout the paper's life, its farewell note exhibited a mixture

Origins of Liberal Feminism in the United States, 1820-1920 (Cambridge, MA, 1996), 159-86; and Louise Michelle Newman, White Women's Rights: The Racial Origins of Feminism in the United States (New York, 1999).

57. This trope continues through the last issue, when the editors included in their "farewell" an indictment of the Iowa state legislature's refusal to grant suffrage to women, putting Iowa "on the same plane with that of the state of Louisiana, where its voters are largely poorly educated colored men." WS 24:7 (Nov. 1911), 2.

58. A notable example of suffrage leaders deploying nativist rhetoric is Carrie Chapman Catt, an Iowa and national leader who also served as editor of the Woman's Standard, 1890-1892. In a speech at the 1894 annual meeting of the IWSA, Catt declared, "This government is menaced with great danger ... in the voices possessed by the males in the slums of the cities and the ignorant foreign vote." For Catt, the only way to prevent "the hoodlums of Chicago" from "reproduc[ing] the horrors of the Old World" is to take the vote from "the slums" and give it to women. Although the Standard did not reprint this speech since it was on a publishing hiatus at the time, the management and editors would have certainly heard the speech at the annual meeting. See "Iowa Annual Meeting," The Woman's Journal, 12/15/1894, 394.

59. Noun, Strong-Minded Women, 260. 
of frustration, hope, and positive spin. Deviating from the grand rhetoric of the first issue regarding the paper's goals, editor Mary Coggeshall insisted that the "purpose of the founders had largely been realized" and so the paper was no longer necessary. According to Coggeshall, the paper had been created to communicate between the state suffrage association and local clubs; the permanent headquarters in Des Moines and the corresponding secretary could now facilitate that communication.

Read in tandem with the rest of the farewell address and with minutes from the Iowa Equal Suffrage Association executive committee, however, a somewhat different picture emerges. In the years leading up to its demise, the Standard struggled to find writers, financial support, and, most importantly, leadership. ${ }^{60}$ Coggeshall, who had also served as the paper's first editor, returned in 1910 to take over the paper at the age of 74. Although she continued the work, her energy was depleted.61 After the Iowa legislature defeated another woman suffrage amendment in 1911, friends reported that Coggeshall "left the Capitol with pale face, broken look, and trembled lip." 62 She died in December 1911, a month after the publication of the final issue of the Standard.

In her farewell piece, Coggeshall had written, "After the editor's resignation two months before the convention, no one has appeared ready to take the place, but if in the enlarged work of the future an organ for the society is deemed essential, the publication . . . will be resumed." 63 Despite a somewhat hopeful ending, the farewell article had a tone of exhaustion, frustration,

60. According to the Iowa Equal Suffrage Association executive committee meeting minutes of December 16, 1910, Coggeshall had requested that subscription rates be raised to support the paper. Ex. Com. Meeting, 12/16/1910, Executive Committee Minutes, 1910-1912, folder 4, box 9, Iowa Women's Suffrage Collection, State Historical Society of Iowa, Des Moines. Sara Egge points out that suffrage workers increased their activity in rural areas between 1900 and 1916. Thus, the newspaper's demise in 1911 suggests that suffrage workers were likely busy with other on-the-ground efforts. It also suggests Coggeshall's importance as a force behind the paper's longevity.

61. Minutes from the executive committee meeting of October 11, 1911, report that after Coggeshall announced her resignation the prior month, there was "difficulty of getting someone to edit it" and thus the paper would be suspended. Ex. Com. Meeting 10/11/1911, Executive Committee Minutes, 1910-1912.

62. Noun, Strong-Minded Women, 268.

63. “Why the Woman's Standard Suspends Publication," WS 24:7 (Nov. 1911), 2. 


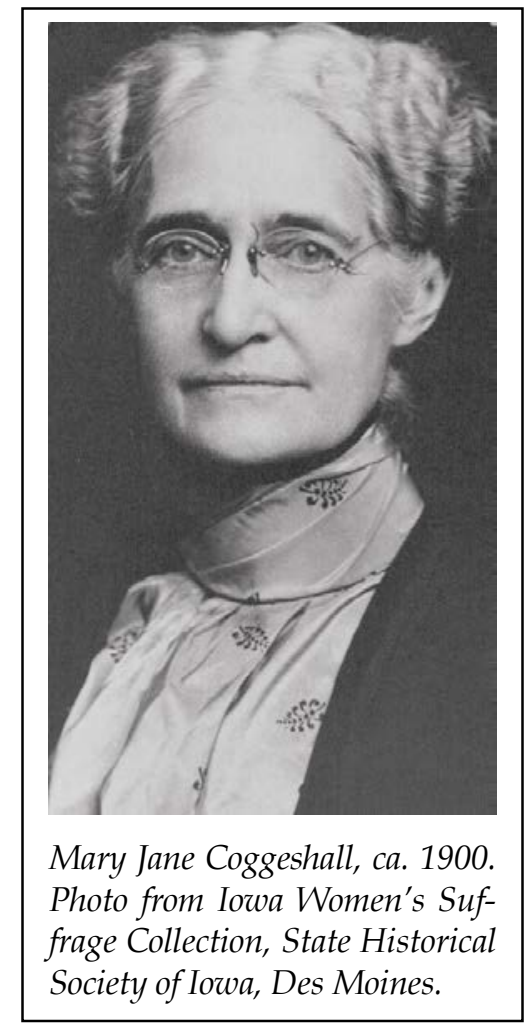

and disappointment. And rightly so, for 25 years of publication and many more years of work still had not won the vote. Yet Coggeshall and the paper's other editors need not have been entirely disappointed, nor should they have concluded that their original goal "to speak to the public" had gone fully unrealized. If the Standard had meant to raise consciousness and give women a voice, it had done so for many. Through farm-based rhetorical appeals, updates on suffrage work in rural areas, and inclusion of some farm-related items beyond suffrage work, the paper did indeed speak to rural women, though to varying degrees. In doing so, it became one way for the imagined farm woman "Peggy" to join with the many women insisting that "we are people," too. ${ }^{64}$

64. “We the People," WS 1:2 (Oct. 1886), 1. 